\title{
UJI COBA PRODUKSI MIKROORGANISME PENGDEGRADASI (PENGHANCUR) SAMPAH PLASTIK
}

\section{Elpawati}

\begin{abstract}
ABSTRAK
Limbah plastik tanpa perlakuan khusus membutuhkan setidaknya lima puluh (50) tahun untuk menjadi terdegradasi. produksi mikroorganisme mungkin memecahkan masalah dalam mendegradasi limbah plastik, khususnya plastik non-daur ulang. Oleh karena itu, produksi limbah biodegradable diharapkan untuk memperoleh manfaat potensial. Metode dalam penelitian ini adalah: - (i) isolasi plastik limbah-mikroorganisme pengurai, (ii) penentuan limbah plastik polietilen terdegradasi, (iii) physiologycal dan tes biokimia pada plastik polietilen-mikroorganisme pengurai, (iv) uji lapangan dan tes produksi. Penelitian ini bertujuan: - (1) untuk menghasilkan plastik-mikroorganisme pengurai, (2) untuk memperoleh mikroorganisme potensial dalam mendegradasi plastik. Hasil penelitian dapat disimpulkan: Jenis mikroorganisme yang dapat mendegradasi plastik Diperoleh sebanyak 32 isolat dari hasil isolasi mikroorganisme dari sampah plastik polietilen dari tempat pembuangan akhir sampah Ciputat. Sebanyak 32 isolat tersebut dimurnikan di agar miring untuk uji selanjutnya' Ditemukan Kekuatan Mikroorganisme Dapat Menghancurkan Plastik. Sebanyak 32 isolat yang berhasil dimurnikan dilakukan uji penentuan degradasi plastik polietilen dengan inkubasi selama 1 bulan, dishaker inkubator pada agitasi $130 \mathrm{rpm}$ dalam kondisi suhu ruang. Bakteri yang paling kuat medegradasi plastik polietilen pada kondisi laboratorium selama inkubasi satu bulan adalah isolat 22 TSB dengan persentase degradasi sebesar 17.9245\% dengan memiliki ciri berbentuk batang dan termasuk bakteri gram positif serta tidak berspora. Penelitian telah berjalan untuk melakukan uji coba degradasi sampah organik. Hasil pengamatan sementara uji coba degradasi terhadap daun poliandra di atas mencapai 99\% yang dilakukan di Rumah Kompos UIN Jakarta. Jumlah mikroorganisme yang mendegradasi plastik, jumlah awal ketika akan diinkubasi sebanyak 1.07 × 108 setelah inkubasi selama satu bulan jumlah mikroorganisme sebanyak $3.08 \times 106$.
\end{abstract}

Kata kunci: bakteri, inkubasi, isolasi, persentase, plastik polyethylen 


\begin{abstract}
Plastic waste without specific treatment needs at least fifty (50) years to be degraded. production of microorganisms may solve the problem in degrading the plastic waste, particularly non-recyclable plastic. Therefore, the production of biodegradable waste is expected to obtain the potential benefits. The method in this research are: - (i) isolate microorganisms decomposing the plastic waste, (ii) the determination of degradable polyethylene plastic waste, (iii) physiologycal and biochemical tests on polyethylene plasticdecomposing microorganisms, (iv) field testing and production tests. This study aims to: (1) to produce plastic-decomposing microorganisms, (2) to obtain the potential of microorganisms to degrade the plastic. The results of this study concluded: type of microorganisms that can degrade the plastic obtained a total of 32 isolates of microorganisms isolated from polyethylene plastic waste from landfill Ciputat. A total of 32 isolates were purified in order to be tilted to further test 'Found Strength Plastic Destroy microorganisms. A total of 32 isolates were successfully purified to test the determination of the degradation of polyethylene by incubation for 1 month, dishaker incubator at $130 \mathrm{rpm}$ agitation in room temperature conditions. Bacteria most powerful medegradasi polyethylene plastic in laboratory conditions for the incubation of one month is 22 isolates TSB with degradation percentage of $17.9245 \%$ with rod-shaped and has the characteristics including gram-positive bacteria and not berspora. Research has been running for testing organic waste degradation. Observations while trials against leaf poliandra degradation over $99 \%$ done at Home Compost UIN Jakarta. The number of microorganisms that degrade the plastic, the amount will be incubated as early as 1:07 x 108 after incubation for one month the number of microorganisms as 3:08 x 106.
\end{abstract}

Keywords: bacteria, incubation, isolation, percentage, plastic polyethylen

\section{PENDAHULUAN}

Sampah plastik tanpa perlakuan adalah limbah yang memerlukan waktu lima puluh tahun untuk terdegradasi (hancur). Saat ini sampah plastik di lingkungan masyarakat menumpuk dimana-mana, sebagian besar sampah plastik di lingkungan kita tidak dapat didaur ulang (bungkus supermi, bungkus cappuccino dan lain-lain). Unit-unit pengolahan sampah yang ada saat ini mengalami kesulitan mengelola sampah plastik yang irreversible. Untuk mengatasi permasalah ini perlu diproduksi suatu mikroorganisme yang dapat mengurai sampah plastik khususnya yang tidak bisa didaur ulang, sehingga sampah-sampah plastik tersebut dapat diproduksi menjadi produk-produk yang bermanfaat.

Meningkatnya polusi lingkungan dan limbah yang tidak dapat diperbaharui dan didegradasi maka mendorong adanya penelitian dan kajian di bidang biosintetik dan biodegradasi material (Lee et. al., 2005). 
Salah satu limbah yang tidak dapat dihancurkan adalah limbah plastik. Plastik merupakan produk polimerisasi sintetik, bisa juga terdiri dari zat lain untuk meningkatkan performa atau ekonomi.

Plastik sintetik merupakan plastik yang non-degradable dan penyebab masalah pembuangan limbah dan pemicu polusi lingkungan (Joshi, 2010). Bioplastik (polihidroksialkanoat) merupakan petroleum yang baik derivate plastik sintetik karena memiliki struktur kimia dan fisika yang sama. Keuntungan utama pada bioplastik adalah bahan organik biologis yang dapat mendegradasi plastik secara lengkap menjadi $\mathrm{CO} 2$ dan air dibawzah kondisi lingkungan alami oleh aktivitas enzimatik mikroorganisme (Arshad et. al., (2007) dan Bertrand et. al., (1990).

Mikroorganisme yang dapat mendegradasi plastik lebih dari 90 genus yaitu dari jenis bakteri dan fungi, diantaranya; Bacillus megaterium, Pseudomonas sp., Azotobacter, Ralstonia eutropha, Halomonas sp., dan lain-lain. Senyawa yang didegradasi yaitu bioplastik PHB (Poly-3-hydroxy-butyric acid) yang merupakan senyawa yang diproduksi oleh mikroorganisme bioplastik sebagai sumber cadangan makanan ketika kondisi nutrisi berkurang (Luegne et. al., 2003).

Selain itu, perkembangan penggunaan energi dan produksi limbah sangat meningkat, negara membutuhkan limbah yang renewable untuk program penghematan energi dan pengendalian pelepasan gas rumah kaca. Sejumlah barangbarang yang diproduksi dan di kemas sangat berkembang dan membuat pembuangan limbah menjadi masalah untuk negara akhirakhir ini. Masalah ini memicu dalam penanganan limbah berdasarkan biologis dan polimer yang mampu didegradasi. Selain itu, perkembangan penggunaan energi dan produksi limbah sangat meningkat, negara membutuhkan limbah yang renewable untuk program penghematan energi dan pengendalian pelepasan gas rumah kaca. Sejumlah barangbarang yang diproduksi dan dikemas sangat berkembang dan membuat pembuangan limbah menjadi masalah untuk negara akhirakhir ini. Masalah ini memicu dalam penanganan limbah berdasarkan biologis dan polimer yang mampu didegradasi. Untuk itu penelitian ini bertujuan untuk menghasilkan mikroorganisme yang dapat mendegradasi plastik dan untuk menemukan berapa besar kekuatan mikroorganisme tersebut menghancurkan plastik. Oleh karena itu menjadi penting dilakukannya penelitian untuk mencari, mengidentifikasi, memproduksi, dan mengaplikasikan mikroorganisme yang mampu mendegradasi limbah plastik. Hal ini akan memberikan dampak yang sangat baik bagi pengelolaan limbah yang ramah lingkungan.

\section{METODE PENELITIAN}

\section{Alat dan Bahan}

1. Alat

Alat yang digunakan pada penelitian ini adalah cawan petri, tabung reaksi, Erlenmeyer, ose, bunsen, Laminar Air Flow (LAF), inkubator, autoklaf, refrigerator, sentrifugal, $\mathrm{pH}$ meter, 
termometer, miroskop cahaya, dan mikropipet.

\section{Bahan}

Bahan yang digunakan pada penelitian ini adalah sampel limbah organik (plastik), media Nutrient Agar (NA), Nutrient Broth (NB), Tryptic Soy Agar (TSA), Tryptic Soy Broth (TSB), alkohol 70\%, akuades, dan spirtus.

\section{Cara Kerja}

\section{Isolasi}

\section{Mikroorganisme}

\section{Pendegradasi Plastik dari Limbah} Plastik Polietilen

Sampah plastik polietilen yang diambil dari tempat pembuangan sampah akhir Kampung Utan Ciputat dicuci dengan akuades steril lalu digunting dengan gunting steril. Kemudian diinokulasikan ke media akuades steril berisi $100 \mathrm{ml}$ dalam erlenmeyer $250 \mathrm{ml}$. Di lakukan seri pengenceran dari 10-1- 10-6 dengan $\mathrm{NaCl}$ steril $0,9 \%$. Tiga pengenceran terakhir diambil $0,1 \mathrm{ml}$ untuk diinokulasikan ke media NA dan TSA. Lalu disebar dengan batang L kemudian diinkubasi di inkubator pada suhu 37oC selama tujuh hari. Setelah tujuh hari inkubasi diamati pertumbuhan koloni. Koloni yang tumbuh distreak ke media cawan petri NA dan TSA kemudian inkubasi kembali pada suhu $37 \mathrm{oC}$ selama 7 hari. Koloni yang tumbuh kemudian dimurnikan ke media agar miring NA dan TSA untuk uji selanjutnya.

\section{Penentuan Degradasi Limbah Plastik Polietilen}

Plastik polietilen ditimbang (berat awal) kemudian dicuci dengan air akuades steril dan disemprot dengan alkohol $70 \%$. Plastik tersebut dimasukkan ke erlenmeyer $100 \mathrm{ml}$ yang berisi media NB dan TSB sebanyak $50 \mathrm{ml}$ secara aseptik. Lalu diinokulasikan sebanyak 2 lup isolat bakteri ke media tersebut. Kemudian diinkubasikan dishaker inkubator pada suhu ruang, dengan agitasi $130 \mathrm{rpm}$ selama satu bulan. Setelah satu bulan inkubasi, plastik polietilen dicuci dengan akuades steril dan disemprot dengan alkohol dikering udarakan kemudian di timbang (berat akhir). Penentuan persentase degradasi plastik oleh mikroorganisme yaitu dengan cara:

$\%$ degradasi $=1$ - berat akhir $\times 100 \%$ berat awal

\section{Uji Fisiologis dan Biokimiawi} Mikroorganisme Pendegradasi Plastik Polietilen

Bakteri yang berpotensi pendegradasi limbah plastik diuji fisiologisnya yaitu: morfologi, warna, tekstur, pewarnaan gram dan pewarnaan spora, dengan mikroskop cahaya.

\section{Uji Coba Lapang}

Delapan isolat dalam kultur cair media NB dan TSB sebanyak $50 \mathrm{ml}$ yang diinkubasi selama dua hari. Plastik 
polietilen di timbang (berat awal) lalu dicuci dengan akuades steril dan disemprotkan dengan alkohol 70\% ditransfer ke media yang bersisi kultur bakteri tersebut secara aseptik. Untuk uji lapang : Plastik yang sudah disterilisasi diisi dengan kompos kering sebagai media di lapang, di tambahkan dengan isolat bakteri kultur cair dan plastik polietilen lalu di tanam di kedalaman tanah $5 \mathrm{~cm}$. Diinkubasi selama satu bulan di kedalamn tanah 5 $\mathrm{cm}$ di depan halaman rumah kompos UIN Jakarta. Setelah satu bulan inkubasi plastik polietilen di cuci bersih dengan akuades steril dan disemprot dengan alkohol 70\% lalu dikering udarakan untuk ditimbang (berat akhir). Untuk kontrol : kompos kering sebgai media lapang, ditambahkan dengan plastik polietilen dan media NB dan TSB $50 \mathrm{ml}$ tanpa isolat bakteri. Penentuan persentase degradasi plastik oleh baktiri pada kondisi lapang yaitu dengan cara:

$\%$ degradasai $=(1-$ berat akhir $) \times 100 \%$

(berat awal)

\section{Uji Produksi}

Mikroorganisme (bakteri) yang berpotensi pendegradasi plastik polietilen berdasarkan uji lab dilakukan uji coba lapang dan uji produksi yaitu dengan cara produksi menggunakan Labu Erlenmeyer. Medium kaya akan nutrisi digunakan dengan menetapkan $\mathrm{pH}$ nya sebelum dilakukan proses sterilisasi. Sebanyak $10 \mathrm{ml}$ medium ditempatkan pada Erlenmeyer $250 \mathrm{ml}$, diinokulasi dengan koloni bakteri yang berasal dari agar miring sebanyak 2 lup. Kemudian diinkubasi selama satu hari pada shaker dengan kecepatan 150 rpm pada suhu $30 \mathrm{oC}$.

Sebanyak $5 \mathrm{ml}$ inokulum diinokulasikan kedalam medium NB dan TSB (50 ml) dalam Erlenmeyer 500 ml. kemudian diinkubasi dengan menggunakan shaker dengan kecepatan $150 \mathrm{rpm}$ pada suhu 30 oC. Pemeriksaan sampel dilakukan tiap 24 jam sekali dengan mengambil sebanyak $4 \mathrm{ml}$ sampel untuk mengukur $\mathrm{pH}$ meter agar pertumbuhan bakteri tetap optimum.

Produksi dalam Fermentor. Medium yang kaya akan nutrisi sebanyak $10 \mathrm{ml}$ dimasukkan ke dalam Erlenmeyer 250 $\mathrm{ml}$ yang telah ditetapkan $\mathrm{pH}$ nya sebelum sterilisasi, diinokulasikan dengan koloni bakteri sebanyak 2 lup. Kemudian diinkubasi selama 1 hari untuk bakteri shaker dengan kecepatan $150 \mathrm{rpm}$ pada suhu 30oC. inokulum sejumlah $5 \mathrm{ml}$ diinokulasikan ke medium $50 \mathrm{ml}$ dalam Erlenmeyer berukuran $500 \mathrm{ml}$. diinkubasikan selama 2 hari pada shaker dengan kecepatan 150 rpm pada suhu 30oC, kemudian diinokulasikan ke dalam fermentor. Sebanyak $100 \mathrm{ml}$ inokulum diinokulasikan ke dalam fermentor yang berisi medium sebanyak 1,1 liter dan telah diatur kondisi optimumnya yaitu pada $\mathrm{pH} 7$ dan suhu $30 \mathrm{oC}$, kecepatan agitasi pada 12 jam pertama adalah 300 rpm kemudian ditingkatkan kecepatan agitasinya secara teratur sampai mencapai 600 rpm. Fermentasi dilakukan selama 4 hari (96 jam) untuk 
bakteri dan 7 hari untuk fungi. Pada setiap jam tertentu dilakukan pengambilan sampel pada fermentor secara aseptis. Untuk tahap selanjutnya dilakukan pada fermentor yang berisi medium 2,2 L, 3,3 L, 4,4 L, dan seterusnya dengan proses yang sama.

\section{HASIL DAN PEMBAHASAN}

\section{Jenis mikroorganisme yang dapat mendegradasi plastik}

Diperoleh sebanyak 32 isolat dari hasil isolasi mikroorganisme dari sampah plastik polietilen yang diambil dari tempat pembuangan akhir sampah di daerah Kampung Utan Ciputat menggunakan media NA dan TSA. Sebanyak 32 isolat tersebut dimurnikan di agar miring untuk uji selanjutnya (Gambar 1).

\section{Ditemukan Kekuatan Mikroorganisme Dapat Menghancurkan Plastik}

Sebanyak 32 isolat yang berhasil dimurnikan dilakukan uji penentuan degradasi plastik polietilen dengan inkubasi selama 1 bulan, dishaker inkubator pada agitasi 130 rpm dalam kondisi suhu ruang.
Diperoleh delapan isolat yang berpotensi sebagai pendegradasi plastik polietilen deng persentase yang berbeda.

oleh isolat 6 TSB sebesar $12.7659 \%$ dan isolat 22 media TSB sebesar 17.9245\%, selanjutnya isolat yang lain memiliki kemampuan degradasi plastik sebesar: isolat 1 TSB (6.6037\%), isolat 11 TSB (4.7619\%), isolat $17 \mathrm{NB}(4.7619 \%)$, isolat $15 \mathrm{NB}$ (5.8252\%), isolat $30 \mathrm{NB}(6.9767 \%)$, dan isolat $21 \mathrm{NB}$ (5.6338\%) (Tabel 2).

$\mathrm{Ke}$ delapan isolat yang potensial pendegradasi plastik polietilen dikarakterisasi secara morfologi, bentuk, pewarnaan Gram, dan pewarnaan spora. Dari ke delapan tersebut isolat 1 TSB termasuk Gram negatif bentuk bulat, tidak berspora. Isolat 6 TSB termasuk Gram negatif bentuk bulat dan berspora. Isolat 11 TSB termasuk Gram negatif, bentuk bulat dan tidak berspora. Isolat 22 TSB termasuk bakteri Gram positif, berbentuk batang dan tidak berspora. Isolat $15 \mathrm{NB}$ termasuk bakteri Gram negatif berbentuk bulat. Isolat 21 NB termasuk bakteri Gram positif berbentuk batang dan tidak berspora. Isolat 30 NB termasuk bakteri Gram negatif bentuk bulat. Isolat $17 \mathrm{NB}$ termasuk bakteri Gram negatif bentuk bulat (Gambar 2).
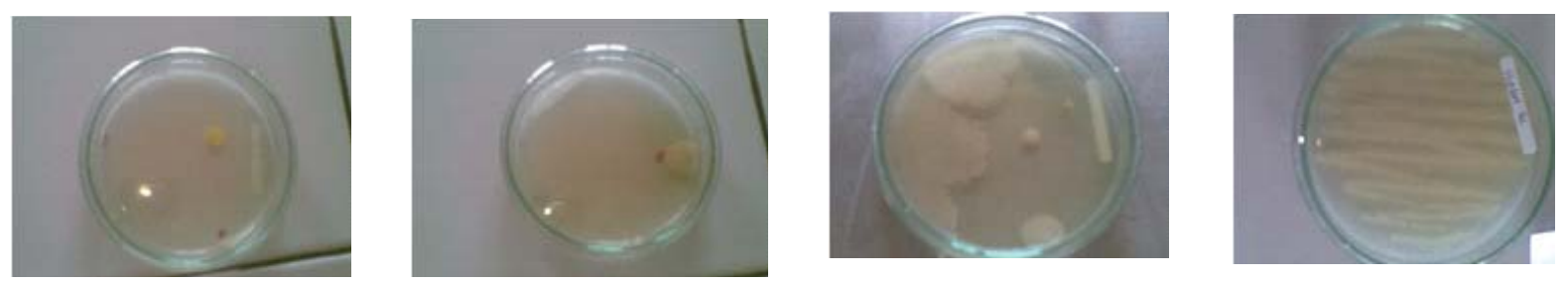

Gambar 2. Isolat bakteri hasil isolasi dari sampah plastik polietilen dengan media NA dan TSA 
Tabel 4. Ciri-ciri bakteri hasil isolasi dari sampah plastik polietilen

\begin{tabular}{|c|c|c|}
\hline No & Isolat & Keterangan \\
\hline 1 & isolat 1 & warna putih, bentuk bulat \\
\hline 2 & isolat 2 & warna putih susu, bergelombang \\
\hline 3 & isolat 3 & warna putih susu, bentuk bulat \\
\hline 4 & isolat 4 & warna putih, bentuk bulat \\
\hline 5 & isolat 5 & warna putih, bentuk bulat cembung ditengah \\
\hline 6 & isolat 6 & warna putih kekuningan, bentuk bulat \\
\hline 7 & isolat 7 & warna putih, bentuk bulat ditengah bulat bergerigi \\
\hline 8 & isolat 8 & warna putih, bergerigi di tepi \\
\hline 9 & isolat 9 & warna putih, bentuk tidak beraturan \\
\hline 10 & isolat 10 & warna putih, bergerigi \\
\hline 11 & isolat 11 & warna putih transparan \\
\hline 12 & isolat 12 & warna putih transparan, bergerigi di tepi \\
\hline 13 & isolat 13 & warna putih, bentuk bulat \\
\hline 14 & isolat 14 & warna putih susu, bentuk bulat cembung ditengah \\
\hline 15 & isolat 15 & warna kuning transparan, bulat \\
\hline 16 & isolat 16 & warna kuning, bulat \\
\hline 17 & isolat 17 & warna putih, bulat \\
\hline 18 & isolat 18 & warna putih, bentuk bulat \\
\hline 19 & isolat 19 & warna kuning terang, bentuk bulat \\
\hline 20 & isolat 20 & warna putih, bentuk bulat \\
\hline 21 & isolat 21 & warna putih, bentuk bulat \\
\hline 22 & isolat 22 & warna abu-abu putih, bergerigi \\
\hline 23 & isolat 23 & warna putih keruh, bulat \\
\hline 24 & isolat 24 & $\begin{array}{l}\text { warna putih transparan, bentuk bulat ditengah terdapat } \\
\text { percabangan }\end{array}$ \\
\hline 25 & isolat 25 & warna krem, bulat \\
\hline 26 & isolat 26 & warna krem, bentuk tidak beraturan \\
\hline 27 & isolat 27 & warna putih krem, bulat \\
\hline 28 & isolat 28 & warna putih, bentuk tidak beraturan \\
\hline 29 & isolat 29 & warna putih, berserabut tidak beraturan \\
\hline 30 & isolat 30 & warna putih susu, bulat \\
\hline 31 & isolat 31 & warna putih krem, bulat cembung ditengah \\
\hline 32 & Isolat 32 & warna putih, bergerigi \\
\hline
\end{tabular}


Tabel 5. Penentuan degradasi palstik polietilen oleh isolat bakteri

\begin{tabular}{|c|c|c|c|c|c|}
\hline No & Nama Isolat & Berat Awal & Berat Akhir & $\begin{array}{c}\text { Hasil } \\
\text { Pengurangan }\end{array}$ & \% Degradasi \\
\hline 1 & Isolat $1 \mathrm{TSB}$ & 0.0106 & 0.0099 & 0.0007 & 6.6037 \\
\hline 2 & Isolat 2 TSB & 0.0097 & 0.0097 & 0 & 0 \\
\hline 3 & Isolat 3 TSB & 0.0097 & 0.0097 & 0 & 0 \\
\hline 4 & Isolat $4 \mathrm{TSB}$ & 0.0096 & 0.0095 & 0.0001 & 1.0416 \\
\hline 5 & Isolat 5 TSB & 0.0092 & 0.0092 & 0 & 0 \\
\hline 6 & Isolat $6 \mathrm{TSB}$ & 0.0094 & 0.0082 & 0.0012 & 12.7659 \\
\hline 7 & Isolat 7 TSB & 0.0089 & 0.0089 & 0 & 0 \\
\hline 8 & Isolat 8 TSB & 0.0100 & 0.0100 & 0 & 0 \\
\hline 9 & Isolat 9 TSB & 0.0108 & 0.0106 & 0.0002 & 1.8518 \\
\hline 10 & Isolat $10 \mathrm{TSB}$ & 0.0109 & 0.0107 & 0.0002 & 1.8348 \\
\hline 11 & Isolat $11 \mathrm{TSB}$ & 0.0105 & 0.0100 & 0.0005 & 4.7619 \\
\hline 12 & Isolat $12 \mathrm{TSB}$ & 0.0105 & 0.0105 & 0 & 0 \\
\hline 13 & Isolat $13 \mathrm{TSB}$ & 0.0084 & 0.0082 & 0.0002 & 2.3809 \\
\hline 14 & Isolat $22 \mathrm{TSB}$ & 0.0106 & 0.0087 & 0.0019 & 17.9245 \\
\hline 15 & Isolat $32 \mathrm{TSB}$ & 0.0090 & 0.0088 & 0.0002 & 2.2222 \\
\hline 16 & Isolat $16 \mathrm{NB}$ & 0.0114 & 0.0114 & 0 & 0 \\
\hline 17 & Isolat $17 \mathrm{NB}$ & 0.0105 & 0.0100 & 0.0005 & 4.7619 \\
\hline 18 & Isolat $31 \mathrm{NB}$ & 0.0098 & 0.0098 & 0 & 0 \\
\hline 19 & Isolat $14 \mathrm{NB}$ & 0.0088 & 0.0088 & 0 & 0 \\
\hline 20 & Isolat $15 \mathrm{NB}$ & 0.0103 & 0.0097 & 0.0006 & 5.8252 \\
\hline 21 & Isolat $30 \mathrm{NB}$ & 0.0086 & 0.0080 & 0.0006 & 6.9767 \\
\hline 22 & Isolat $29 \mathrm{NB}$ & 0.0090 & 0.0090 & 0 & 0 \\
\hline 23 & Isolat $28 \mathrm{NB}$ & 0.0085 & 0.0083 & 0.0002 & 2.3529 \\
\hline 24 & Isolat $27 \mathrm{NB}$ & 0.0123 & 0.0121 & 0.0002 & 1.6260 \\
\hline 25 & Isolat $21 \mathrm{NB}$ & 0.0071 & 0.0067 & 0.0004 & 5.6338 \\
\hline
\end{tabular}
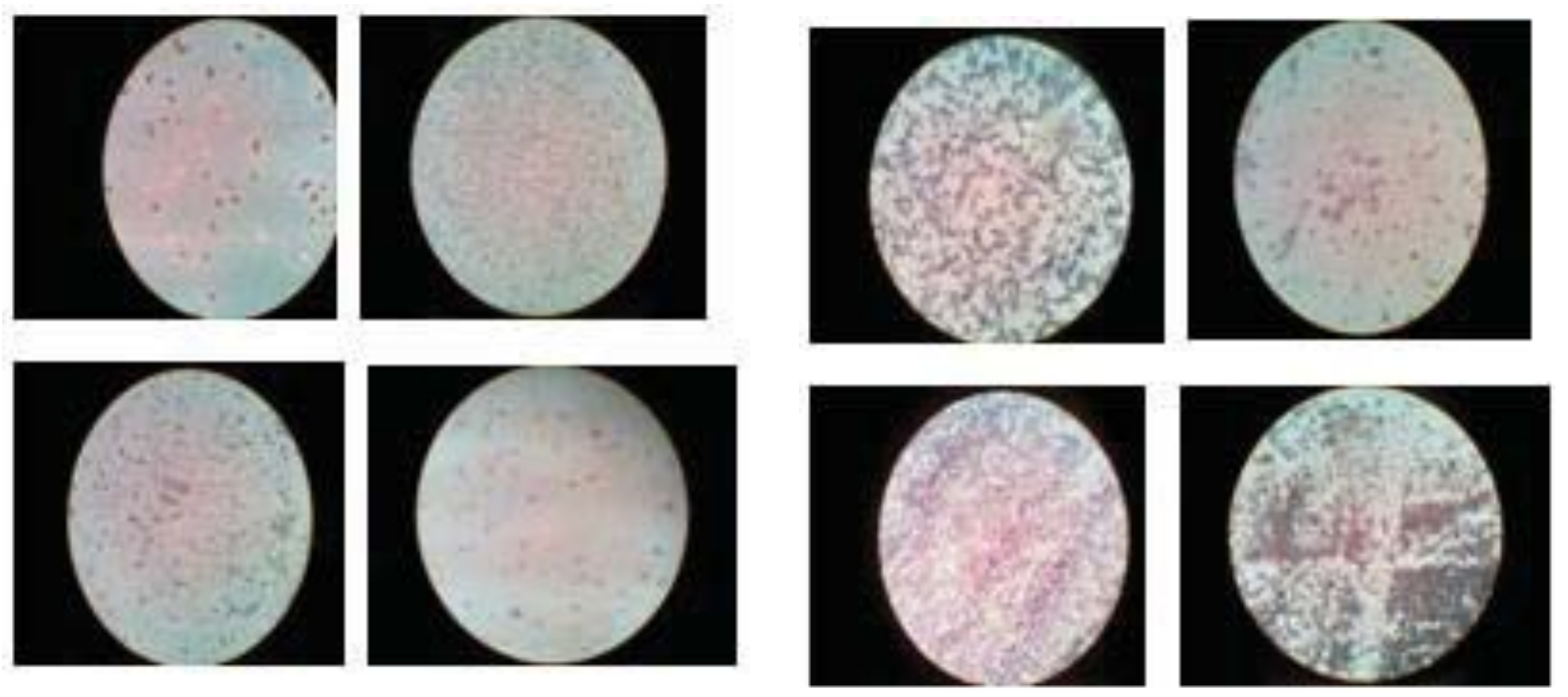

Gambar 3. Karakterisasi bakteri pendegradasi plastik polietilen 
Tabel 6. Degradasi plastik polietilen pada kondisi lapang

\begin{tabular}{lllll}
\hline No & Jenis Isolat & Berat Awal & Berat Akhir & \% Degradasi \\
\hline 1 & Isolat 17 NB & 1.0075 & 1.0118 & -0.4267 \\
2 & Isolat 30 NB & 1.0058 & 0.9983 & 0.7456 \\
3 & Isolat 1 TSB & 1.0069 & 0.9350 & 7.1407 \\
4 & Isolat 15 TSB & 1.0155 & 1.0092 & 0.6203 \\
5 & Isolat 11 TSB & 1.0201 & 0.9632 & 5.5778 \\
6 & Isolat 22 TSB & 1.0111 & 0.9890 & 2.1089 \\
7 & Isolat 21 NB & 1.0192 & 1.0189 & 0.0245 \\
8 & Isolat 6 TSB & 1.0315 & 1.0237 & 0.7321 \\
\hline
\end{tabular}

\section{Uji Coba Lapang}

Ke delapan isolat yang memiliki potensi pendegradasi plastik polietilen dalam kondisi laboratorium akan diujikan di kondisi lapang dengan menggunakan media tambahan yaitu kompos organik (daun kering)..

Dari ke delapan isolat tersebut yang berpotensi tinggi mendegradasi plastik adalah isolat 1 TSB dengan persentase degradasi sebesar $7.1407 \%$ (Tabel 3). Hal ini dikarenakan bakteri mengalami fase adaptasi yang lama dengan media baru dan kondisi lingkungan yang berbeda.

Mekanisme degradasi belum diketahui. Tidak ada robek dibagian plastik, namun berat akhirnya mengalami pengurangan dibandingkan dengan berat awal. Ini mungkin disebabakan oleh senyawa yang disekresikan oleh mikroba yang dapat memecahkan struktur yang kompleks dari molekuler plastik (Kathiresan, 2003).

Tabel 7. Degradasi daun poliandra oleh mikroorganisme pada kondisi laboratorium

\begin{tabular}{lllll}
\hline No & Jenis Isolat & Berat Awal & Berat Akhir & \% Degradasi \\
\hline 1 & Isolat 17 NA & 1.0521 & 1.0133 & 74.472 \\
2 & Isolat 30 NA & 1.0474 & 0.0043 & 90.928 \\
3 & Isolat 1 TSA & 1.0478 & 0.0094 & 80.334 \\
4 & Isolat 15 TSA & 1.0495 & 1.0107 & 78.383 \\
5 & Isolat 11 TSA & 1.0408 & 0.0110 & 73.039 \\
6 & Isolat 22 TSA & 1.0559 & 0.0176 & 68.515 \\
7 & Isolat 21 NA & 1.0576 & 0.0134 & 76.736 \\
8 & Isolat 6 TSA & 1.0571 & 0.0149 & 73.905 \\
\hline
\end{tabular}


Maka studi lebih lanjut tentang enzim mikroba atau asam organik untuk degradasi polietilen akan membuka cara untuk menemukan teknologi untuk menurunkan bahan plastik yang dinyatakan berbahaya bagi lingkungan.

Selain itu, bakteri yang berpotensi pendegradasi plastik diujikan ke sampah organik yaitu daun poliandra dengan inkubasi selama satu bulan dalam kondisi laboratorium memiliki degradasi sangat tinggi yaitu dengan persentase degradasi sebesar $90.928 \%$ oleh isolat 30 NB (Tabel 4). Penelitian pengamatan sementara uji coba degradasi terhadap daun poliandra di atas mencapai $99 \%$ yang dilakukan di Rumah Kompos UIN Jakarta.

Jumlah mikroorganisme yang mendegradasi plastik, jumlah awal ketika akan diinkubasi sebanyak 1.07 x $10^{8}$ setelah inkubasi selama satu bulan jumlah mikroorganisme sebanyak $3.08 \times 10^{6 \ldots}$

\section{KESIMPULAN DAN SARAN}

\section{Kesimpulan}

Dari hasil penelitian dan pembahasan di atas dapat disimpulkan: \

1. Bakteri yang paling kuat mengegradasi plastik polietilen pada kondisi laboratorium selama inkubasi selama inkubasi satu bulan adalah isolat 22 TSB dengan persentase degradasi sebesar $17.9245 \%$ dengan memiliki ciri berbentuk batang dan termasuk bakteri gram positif serta tidak berspora.

2. Penelitian telah berjalan untuk melakukan uji coba degradasi sampah organik. Hasil pengamatan sementara uji coba degradasi terhadap daun poliandra di atas mencapai 99\% yang dilakukan di Rumah Kompos UIN Jakarta.

\section{Saran}

Saran dari hasil penelitian adalah:

1. Perlu dilakukan penelitian lanjutan khususnya terhadap bakteri pendegradasi plastik agar didapatkan persentase pendegradsi lebih baik.

2. Perlu dilakukan uji lanjut terhadap bakteri penghancur sampah organik.

\section{DAFTAR PUSTAKA}

Arshad MU, Jamil N, Naheed N, Hasnain S. 2007.Isolation and characterization of poly- $\beta$ hydroxyalkanoate producing bacteria from sewage sample. J Biotechnol Vol6: 1115-1121

Barnard GN and Sanders JKM. 1989. The poly $\beta$-hydroxybutirate granules in in-vivo. J Biol Chem. 264: 3268-3291

Bertrand JL, Ramsay BA, Chavarie C. Isolation and characterization of poly- $\beta$ hydroxyalkanoate producing bacteria from sewage sample. Appl Env Microbiol Vol 56:3133-3138

Joshi PA, and Jaysawal SR. 2010. Isolation and characterization of poly- $\beta$ hydroxyalkanoate producing bacteria from sewage sample. J of Cell and Tissue Research. Vol $102165-2168$ 
Lee MK, Gimore DF, Huss MJ. 2005. Fungal degradation of the bioplastik PHB (Poly-3hydroxy-butyric acid. $\mathrm{J}$ of Polymers and Env. Vol 13 no. 3

Luengo JM, Garcia B, Sandoval A, Naharro G, Olivera R. 2003. Bioplastiks from microorganisms. Current opinion in Microbiology. 6:251260

Madison LL and Huisman GW. 1999. Metabolic engineering of poly(3-hydroxyalkanoate): from DNA to plastik. Microbiol Molecular Biology Reviews. $63: 21-53$

Madison LL and Huisman GW. 1999. Metabolic engineering of poly(3-hydroxyalkanoate): from DNA to plastik. Microbiol Molecular Biology Reviews. $63: 21-53$

Merrick JM, Lundgren DG, Pfister RM. 1965. Morfhological changes in poly $\beta$-hydroxybutirate granules associated with decreased susceptibility of enzymatic hydrolysis. J Bacteriol. 89:234239

Staley JT, Gunsalus RP, Lory S, Perry JJ. 2007. Microbial life. Sinauer Associates

Schlegal HG, Gottshalk, Bartha RV. 1961. Formation and utilization of poly hydroxyl butyric acid by knallgas bacteria (Hydregemonas), Nature (Lond). 191: 463-465

Winferd FD and Robards AW. 1973. Ultra structural study of poly $\beta$ hydroxybutyrate granules from Bacillus cereus. J Bacteriol. 114: 1271-128

* Dosen Prodi Agribisnis FST UIN Syarif Hidayatullah Jakarta (Email: elpawati@uinjkt.ac.id) 
